\title{
Chemistry of Manganese Dioxide Dry Cells. XI. Measurements of the Composition and the Resistance of the Network Within the Cathode Bobbin of Dry Cells
}

\author{
Taketsugu Hirai, and Masataro Fukuda
}

Central Research Lab. Matsushita Electric Industrial Co., Ltd., Kitakawachi-gun, Osaka

A cathode bobbin of a dry cell consists of a molded black mix, that is, a uniform mixture of manganese dioxide and carbon impregnated with wetting fluid. Manganese dioxide acts as a cathode active material and carbon as the path for electronic current toward carbon rod, and these two materials form a porous electrode, in which the wetting fluid is absorbed to work as an electrolyte. Although some works were reported about the relation between electrical resistance and compression of either carbon black only ${ }^{1)}$ or mixtures of manganese dioxide and carbon $^{2)}$, little investigation has been made concerning the characteristics of a bobbin.

In this report, considering that such characteristics of a bobbin depend on the content of manganese dioxide and the wetting fluid in the bobbin, specific resistances of the network of carbon particles and the wetting fluid, the effects of these factors were investigated in relation to the make-up conditions of the bobbin, i.e., mixing ratio (of manganese dioxide to carbon material), composition of the carbon material and the molding pressure. Specific resistance of the network of carbon particles and that of the wetting fluid were tried to be obtained by the analysis of two potential curves corresponding to the electronic current and the ionic current. The results obtained are as follows.

(1) With increasing the mixing ratio (or the content of the natural graphite) in the carbon

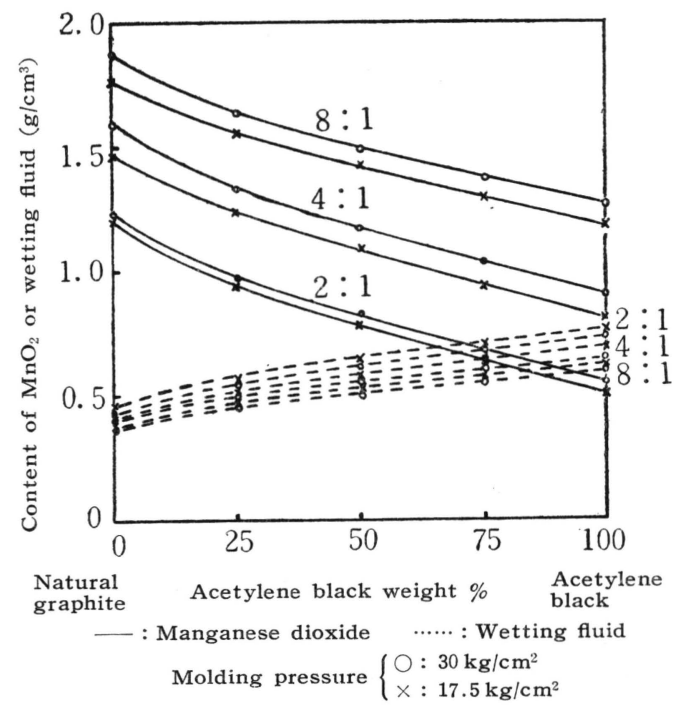

Fig. 1 Relations between the make-up conditions and the content of manganese dioxide or wetting fluid

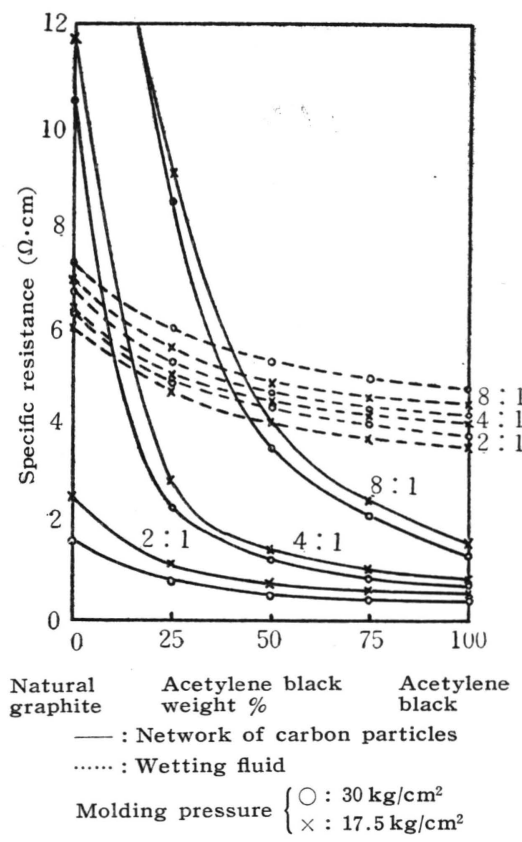

Fig. 2 Relations between the make-up conditions and the specific resistance of network of carbon particles or wetting fluid 
material the wetting fluid content decreased, while the manganese dioxide content, specific resistances of the carbon particle network and of the wetting fluid increased. The effect of molding pressure was rather small (c.f. Fig. 1, Fig. 2).

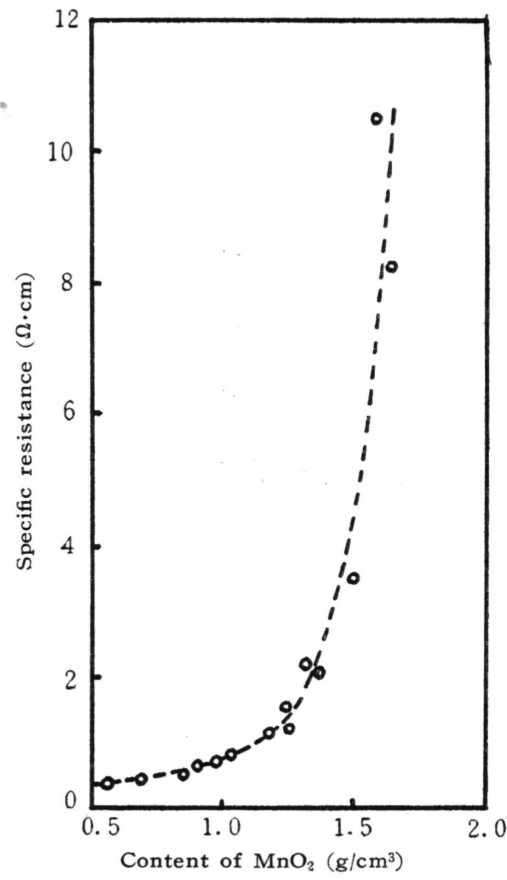

Fig. 3 Relation between specific resistance of network of carbon particles and the content of manganese dioxide

(2) It was difficult to make a bobbin with high content of both manganese dioxide and wetting fluid, and with small specific resistances of the carbon particle network and the wetting fluid, which should be the most ideal and satisfactory bobbin. Therefore, the make-up conditions should be determined in accordance with the request, considering the effects of above factors.

(3) For the bobbin of heavy-duty dry cells, high manganese dioxide content and low network resistance in the bobbin are necessary. These conditions may be determined chiefly by considering the relation between manganese dioxide content and specific resistance of carbon particle

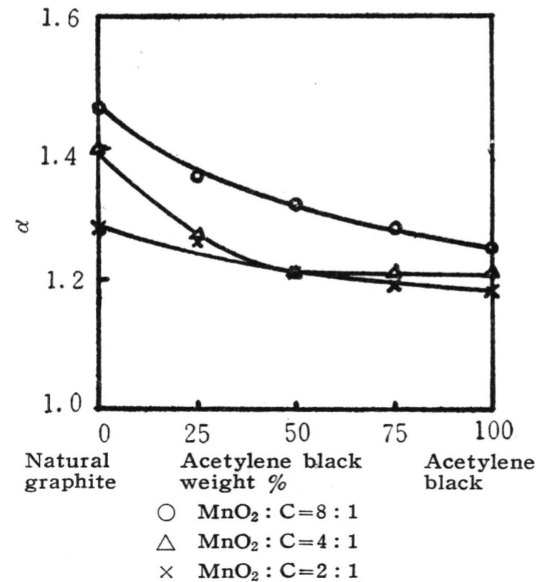

Fig. 4 Changes of $\alpha$ with the make-up conditions of the bobbin

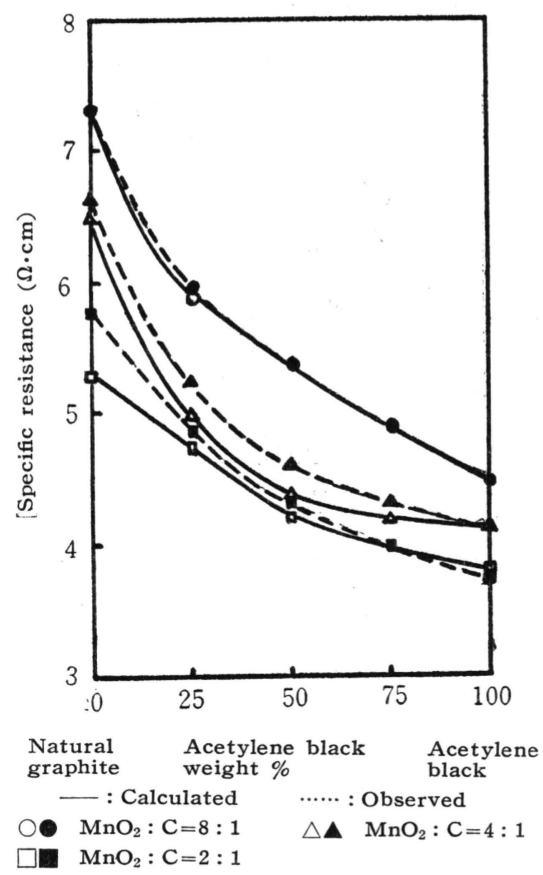

Fig. 5 Comparison between observed and calculated values of specific resistances of wetting fluid in the bobbin network (c.f. Fig. 3). It is thus confirmed that, for a molding pressure of $30 \mathrm{~kg} / \mathrm{cm}^{2}$, mixing ratios of $8: 1$ and $4: 1$ are advisable for acetylene black as a carbon material, and for $1: 1$ mixture of acetylene black and natural graphite, respectively.

(4) The observed and calculated specific resistances of the wetting fluid in the bobbin were compared and it was found that the correction factor $\alpha$ for tortuosity in porous electrode falls in a range 
1.2 to 1.5 (c.f. Fig. 4). Therefore, it is seen that the observed specific resistance of the wetting fluid in the bobbin agrees fairly well with the value calculated in the ordinary way ${ }^{3) 4}$ (i.e., specific resistance of the wetting fluid in an ordinary sense divided by the volume fraction of the wetting fluid in a bobbin, i.e., the porosity of electrode). Thus the calculated specific resistance of the wetting fluid may be considered to be roughly equal to the observed value (c.f. Fig. 5).

(Received Dec. 19, 1960)

\title{
Literature :
}

1) G. Benson, J. Gluck, C. Kaufmann, Trans. Electrochem. Soc. 90, 441 (1946).

2) R. Glicksman, C.K. Morehouse, J. Electrochem. Soc. 103, 149 (1956).

3) J.J. Coleman, Trans. Electrochem. Soc. 90, 545 (1946).

4) S. Matsuno, This Journal 20, 608 (1952).

\section{Fused Salt Electrolysis of Uranium and Chromium Chlorides}

\author{
Tadashi Kuroda and Tadashi Suzuki
}

Electrotechnical Laboratory, Ministry of International Trade and Industry, Tokyo

\section{Introduction}

The electrolysis of uranium and chromium chlorides $\left(\mathrm{UCl}_{4}, \mathrm{CrCl}_{3}\right)$ on the small scale are very helpful for larger scale production of these metals. The electromotive forces of the cells $\mathrm{U} / \mathrm{UCl}_{4}, \mathrm{KCl}+$ $\mathrm{LiCl}$ (eutectic) $/ \mathrm{Cl}_{2}$ (cell 1) and $\mathrm{Cr} / \mathrm{CrCl}_{3}, \mathrm{KCl}+\mathrm{LiCl}$ (eutectic) $/ \mathrm{Cl}_{2}$ (cell 2) were measured at $550^{\circ} \mathrm{C}$. Electrolysis of $\mathrm{UCl}_{4}$ and $\mathrm{CrCl}_{3}$ in fused $\mathrm{KCl}+\mathrm{LiCl}+\mathrm{NaCl}$ (eutectic) were performed as a function of $\mathrm{UCl}_{4}$ or $\mathrm{CrCl}_{3}$ concentration, temperature and current density. Polarization potential and anodic current efficiency were determined precisely.

\section{Experimentals}

It is known that uranium forms a lower halide, $\mathrm{UCl}_{3}$ and chromium forms $\mathrm{CrCl}_{2}$. The theoretical decomposition voltages of many metalchloride were calculated from thermodynamic data by Hamer et $\mathrm{al}^{11}$. The values listed in Table 1 were used for discussion of this study.

Table 1 Decomposition Voltages Calculated by Hamer et al. ${ }^{1)}$ (V)

\begin{tabular}{l|c|c|c|c}
\hline \multicolumn{1}{c|}{ Temp. } & $\left({ }^{\circ} \mathrm{C}\right)$ & 550 & 600 & 800 \\
Reaction & 450 & 2.458 & 2.423 & 2.280 \\
\hline $\mathrm{UCl}_{3} \rightarrow \mathrm{U}+3 / 2 \mathrm{Cl}_{2}$ & 2.530 & 2.111 & 2.078 & 1.974 \\
$\mathrm{UCl}_{4} \rightarrow \mathrm{U}+2 \mathrm{Cl}_{2}$ & 2.181 & 1.505 & 1.474 & 1.352 \\
$\mathrm{CrCl}_{2} \rightarrow \mathrm{Cr}+\mathrm{Cl}_{2}$ & 1.568 & 1.299 & 1.261 & 1.113 \\
$\mathrm{CrCl}_{3} \rightarrow \mathrm{Cr}+3 / 2 \mathrm{Cl}_{2}$ & 1.374 & 3.707 & 3.658 & 3.441 \\
$\mathrm{KCl} \rightarrow \mathrm{K}+1 / 2 \mathrm{Cl}_{2}$ & 3.805 & 3.608 & 3.571 & 3.457 \\
$\mathrm{LiCl} \rightarrow \mathrm{Li}+1 / 2 \mathrm{Cl}_{2}$ & 3.684 & 3.471 & 3.424 & 3.240 \\
$\mathrm{NaCl} \rightarrow \mathrm{Na}+1 / 2 \mathrm{Cl}_{2}$ & 3.566 & & &
\end{tabular}

Terex cell, electrodes and additional device used are shown in Figs. 1 and 2.

$\mathrm{UCl}_{4}$ was prepared by heating the mixture of the oxide and carbon at about $800^{\circ}$ in a stream of pure chlorine. $\mathrm{CrCl}_{3}$ was also prepared by the same method. $\mathrm{UCl}_{4}$ of dendritic form and $\mathrm{CrCl}_{3}$ of powdered form suitable for introduction into the melt were used. Uranium cathode of the cell 1 was prepared by fusion of dendritic uranium, made by fused salt electrolysis of $\mathrm{UCl}_{4}$, in a high frequency induction vacuum furnace. For the cathode of the cell 2 arc-melted chromium was used. For the anodes $6 \mathrm{~mm}$ diam. rods were used. Impurities in fused alkali chloride including $\mathrm{HCl}$, formed as a 